\title{
Co-designing win-win partnerships between agro- industries and smallholders in the palm oil sector in Cameroon
}

\author{
Sadou Haman Djouma ${ }^{(1,4)}$, Laurène Feintrenie ${ }^{(2)}$, Patrice Levang ${ }^{(3,4)}$, Ajaga Nji ${ }^{(1)}$ \\ (1) University of Dschang. Faculty of Agronomy and Agricultural Sciences (FASA). BP 222. Dschang (Cameroon). \\ (2) CIRAD. Forests and Societies Research Unit. Campus International de Baillarguet. TA C-105/D. FR-34398 Montpellier \\ cedex 5 (France). E-mail: laurene.feintrenie@cirad.fr \\ (3) Institut de Recherche pour le Développement (IRD-GRED). 911, Avenue Agropolis. BP 64501. FR-34393 Montpellier \\ cedex 5 (France). \\ ${ }^{(4)}$ Centre for International Forestry Research (CIFOR). c/o IITA. BP 2008. Yaoundé (Cameroon).
}

Received on February 10, 2017; accepted on June 14, 2018; available online 28 June 2018.

This article is distributed under the terms and conditions of the CC-BY License (http://creativecommons.org/licenses/by/4.0)

Description of the subject. To boost the development of the national palm oil sector, one of the most promising moves for the Cameroonian government would be to improve partnerships between agro-industries and smallholders in order to increase the latter's plantation yields and oil extraction rates.

Objectives. Drawing on successful experiences in Southeast Asia, this paper examines the conditions for establishing a winwin partnership between agro-industrial companies and smallholders in the Cameroonian palm oil sector.

Method. The study was carried out in three production basins in the Centre and the Southwest regions of Cameroon where such partnerships were initiated before the collapse of the National Aid Fund for Rural Development (FONADER) in the 1970s. In participatory workshops involving at least twelve stakeholders (palm oil producers, artisanal and industrial millers, intermediaries and agricultural extension services), the participants' knowledge was integrated together through individual and collective reflection, with a guarantee of equal expression and consideration of views. Two workshops followed a strict adaptation of Participatory Prospective Analysis (PPA); a third followed a semi-directed participatory approach. Interactions between participants produced definitions of the systems studied and the variables involved, different plausible future scenarios, and recommendations for decision making.

Results. Access to technical and managerial capacity building, terms of the contract, access to shareholding in the company by smallholders, and legalization of the terms of the contract emerged as the major items that would influence a sustainable partnership between agro-industries and smallholders.

Conclusions. Participatory derived recommendations show that long-term partnerships between agro-industry and smallholders depend on a negotiated contract agreement between the partners to ensure transparency and trust. In addition, a dedicated smallholder department in charge of village plantations within agro-industrial companies can facilitate communication between partners.

Keywords. Elaeis guineensis, joint ventures, Participative Prospective Analysis (PPA), semi-guided prospective analysis, transparency.

Co-construire des partenariats gagnant-gagnant entre agro-industries et planteurs dans la filière huile de palme au Cameroun

Description du sujet. Afin de développer le secteur de l'huile de palme au Cameroun, une des voies les plus prometteuses pour le gouvernement consiste à améliorer les partenariats entre agro-industries et petits planteurs afin d'augmenter les rendements et les taux d'extraction en huile des plantations villageoises.

Objectifs. S'inspirant de l'expérience du développement du secteur de l'huile de palme dans les pays d'Asie du Sud-Est, cet article examine les conditions de mise en œuvre de partenariats gagnant-gagnant entre les entreprises agro-industrielles et les exploitations familiales de la filière.

Méthode. L'étude a été menée dans trois bassins de production des régions du Centre et du Sud-Ouest du Cameroun où ces partenariats avaient été initiés dans les années 1970 avant l'effondrement du Fonds National d'Aide au Développement Rural 
(FONADER). Lors d'ateliers participatifs regroupant au moins douze participants (producteurs d'huile de palme, moulins artisanaux et industriels, intermédiaires et services de vulgarisation agricole), les connaissances des participants sont intégrées, partant d'une réflexion individuelle puis collective, garantissant une expression et une considération égales des points de vue. Deux ateliers ont été organisés suivant une stricte adaptation de la méthode d'Analyse Prospective Participative (PPA) et un troisième atelier suivant une approche participative semi-dirigée. Les interactions entre les participants se focalisent sur la délimitation du système étudié, les énoncés de variables, les différents scénarios plausibles, et des recommandations pour la prise de décision.

Résultats. L'accès au renforcement des capacités techniques et managériales, les termes du contrat, l'accès des petits planteurs à l'actionnariat des agro-industries et la légalisation des termes du contrat ressortent comme les éléments majeurs d'un partenariat durable entre les agro-industries et les petits exploitants.

Conclusions. Les recommandations élaborées de façon participative montrent qu'un partenariat de long terme entre l'agroindustrie et les petits planteurs dépend d'un accord contractuel négocié entre partenaires susceptible d'assurer la transparence et la confiance. De plus, la création au sein des agro-industries d'un département en charge des plantations villageoises faciliterait la communication entre partenaires.

Mots-clés. Elaeis guineensis, coentreprise, Analyse Prospective Participative (PPA), approche participative semi-dirigée, transparence.

\section{INTRODUCTION}

Oil palm (Elaeis guineensis) is native to the countries bordering the Gulf of Guinea where natural palm groves can still be found (Maley, 1999). Oil palm seeds were harvested from the wild and used in food long before the first plantations (Maley, 1999). During the second half of the $19^{\text {th }}$ century, palm oil and kernels became a major export item for West and Central African farmers. From the beginning of the $20^{\text {th }}$ century, the colonial powers started to develop industrial oil palm plantations in both Central Africa and Southeast Asia (Rival \& Levang, 2013).

Until the 1960s, West African countries were the major palm oil producers, and Nigeria ranked first with $43 \%$ of the world's production (Olagunju, 2008). Today, these countries are no longer self-sufficient in palm oil and increasingly resort to imports from Southeast Asia. Malaysia and Indonesia progressively took over the lead and currently cover $85 \%$ of global palm oil production. The success of Southeast Asia has been attributed mostly to effective policies based on both public-private industrial-smallholder partnerships and the creation of industrial estates (Rival \& Levang, 2013). The expansion of perennial crops from the 1980 s to 2000 brought companies into association with smallholders based on a model known as, "Nucleus Estate and Smallholder" (NES), where an industrial plantation (estate) is associated with peripheral smallholders' plantations (plasma) under contract (Levang, 1997).

The development of the palm oil sector in Malaysia began in 1956 under the coordination of the Federal Land Development Authority (FELDA). The aim was to set up families to engage in agricultural production, offering opportunities to the poorest and giving land to those who needed it (Abdullah et al., 1987). On a block of 250 ha, 400 families were resettled, each family receiving 5 ha and good quality seedlings with technical support (Levang, 1997). From the 1990s, the policy of FELDA changed, with a focus on joint ventures between a private enterprise and the State. A contract farming arrangement between small producers and agro-industrial companies supervised by FELDA regulates the settlement of new producers and new factories. The terms of the agreements between smallholders and industries were critical to the benefitsharing results of the oil palm projects (Cramb \& Ferraro, 2012).

In Central African countries, the history of oil palm expansion is also linked to agro-industrial plantations and public policies favoring the rise of palm oil production while developing rural areas (Feintrenie, 2014), as described by Ndjogui et al. (2014) in Cameroon. In 1973, the Program of Development of Village Plantations began in Cameroon with the creation of the National Aid Fund for Rural Development (FONADER). The oil palm development program involved three Cameroonian public companies: "Société Camerounaise de Palmeraies" (SOCAPALM), PAMOL and CDC. Prior to FONADER's collapse in the 1990s (Ndjogui et al., 2014 ), the program had contributed to the creation of 13,000 ha of smallholder plantations shared among 3,100 growers (Bakoumé et al., 2002).

The FONADER partnerships relied on individual contracts concluded between agro-industrial companies and smallholders over a 27-year period (Konings, 1986). These contracts were not negotiated. Loans were made available to smallholders at a $9 \%$ annual interest rate, repayable in 14 years, after a grace period of 6 years corresponding to the period of entry into production. Smallholders were supposed to deliver all of their Fresh Fruit Bunches (FFB) to the industrial mill until their debt was fully repaid. The majority of farmers owning less than 2 ha decided not to deliver their 
production to the mill and engaged instead in smallscale processing, arguing that the interest rates were too high (Elong, 2003; Nkongho et al., 2014b). When the agribusinesses stopped providing transportation of FFB from farm gate to mill, more farmers chose small-scale processing over delivery to industrial mills (Elong, 2003). Furthermore, problems related to the internal structure of FONADER contributed to the failure of the program (Foko, 1994).

A key difference between Central African and Southeast Asian countries is the artisanal extraction of oil from FFB. The existence of an artisanal sector gives smallholders the possibility to be independent from palm oil mills. As a result, all industrial mills face regular competition from artisanal mills for FFB delivery, and oil palm growers do not hesitate to put an end to a partnership with an industry if they are not fully satisfied by the arrangement.

In Cameroon, as in other African countries, oil palm development has become a priority for the government. While agro-industries achieve better FFB yields and higher oil extraction rates ${ }^{1}$, family farming seems more strategic for job creation, poverty reduction and social justice (Rival \& Levang, 2013). Furthermore, since the end of the government-sponsored FONADER development program, smallholder plantations have continued to expand while agro-industries have faced difficulties in growing (Ndjogui et al.,2014).In 2003, the Cameroonian government launched a new smallholder development program through the "Programme de Développement des Palmeraies Villageoises" (PDPV). A first phase from 2003 to 2009 contributed to the development of approximately 7,500 ha of oil palm plantations. In a second phase planned through 2020, the government intends to develop 12,000 ha of smallholder plantations and to create eight micro-mills (Ngom et al.,2016). Where smallholders are close to an industrial mill, they generally sell their FFB production either to the industry or to artisanal mills, depending on the price offered.

The objective of our research is to determine the conditions for establishing a sustainable, win-win partnership between smallholders and agro-industries. What are the prerequisites to achieve such a win-win partnership? How can its long-term sustainability be ensured and past failures be avoided? To tackle this question, the Participatory Prospective Analysis (PPA) developed by Bourgeois \& Jésus (2004) was applied by involving key stakeholders of the oil palm value chain.

\footnotetext{
${ }^{1}$ While $1 \mathrm{t}$ of FFB produces between 120 and $180 \mathrm{~kg}$ of palm oil in an artisanal mill, the same amount would produce $230 \mathrm{~kg}$ if processed in an industrial mill (Bakoumé et al., 2002).
}

\section{METHODS}

A participatory process can prevent conflict and bring stakeholders to identify alternative courses of action to business as usual. During a Participatory Prospective Analysis (PPA) workshop, stakeholders often agree on a management plan and day-to-day planning to work together on development options (Marien \& Bassaler, 2013). The PPA method was considered suitable to tackle the objective of this study because it brought together core stakeholders in an integrative approach to discuss their day-today difficulties face-to-face. The workshops were organized in May 2014 in three of the major palm oil production basins where FONADER was active in the 1970s (Figure 1). Each workshop brought together about 12 knowledgeable participants from the palm oil sector over a period of four days. In the first two workshops, in Eséka (Centre Region) and Ekondo Titi (Southwest Region), we scrupulously applied the PPA method as described by Bourgeois \& Jésus (2004). In the third workshop in Muyuka (Southwest Region), a semi-guided participatory approach was used to assess the effectiveness of the PPA method. In a semi-guided participatory approach, facilitators suggest topics of discussion and stakeholders are invited to express their views in an interactive process.

Lastly, a meeting was organized with officials of the National Union of Palm Oil Producers (in French: Union Nationale des Exploitants de Palmier à huile, UNEXPALM) and the national coordinator of PDPV, both actors on a national scale, to validate the genericity - at a national scale - of the results of the workshops conducted at the local level. This also allowed a comparison and debate on the differences between the viewpoints of local actors and national policymakers.

The selection of participants in the local workshops was carried out to cover the diversity of producers and local actors in the value chain. It was based on previous studies conducted in these sites by CIFOR and CIRAD research teams (Iyabano, 2013; Nchanji et al., 2013; Nkongho et al., 2014a; Nkongho et al., 2014b). Criteria for participant selection were professional status (oil palm grower with a gradient of acreage of the plantation; owner of artisanal mills; member of a producer's organization; employee of agro-industries or retired personnel), gender, and origin (migrant or native). The ability to speak easily in public was also considered by the research team to select participants who would not be reluctant to participate in debates with people they did not know (Table 1).

The PPA workshops were divided into the following four main steps, each lasting one day and described in the following section. 

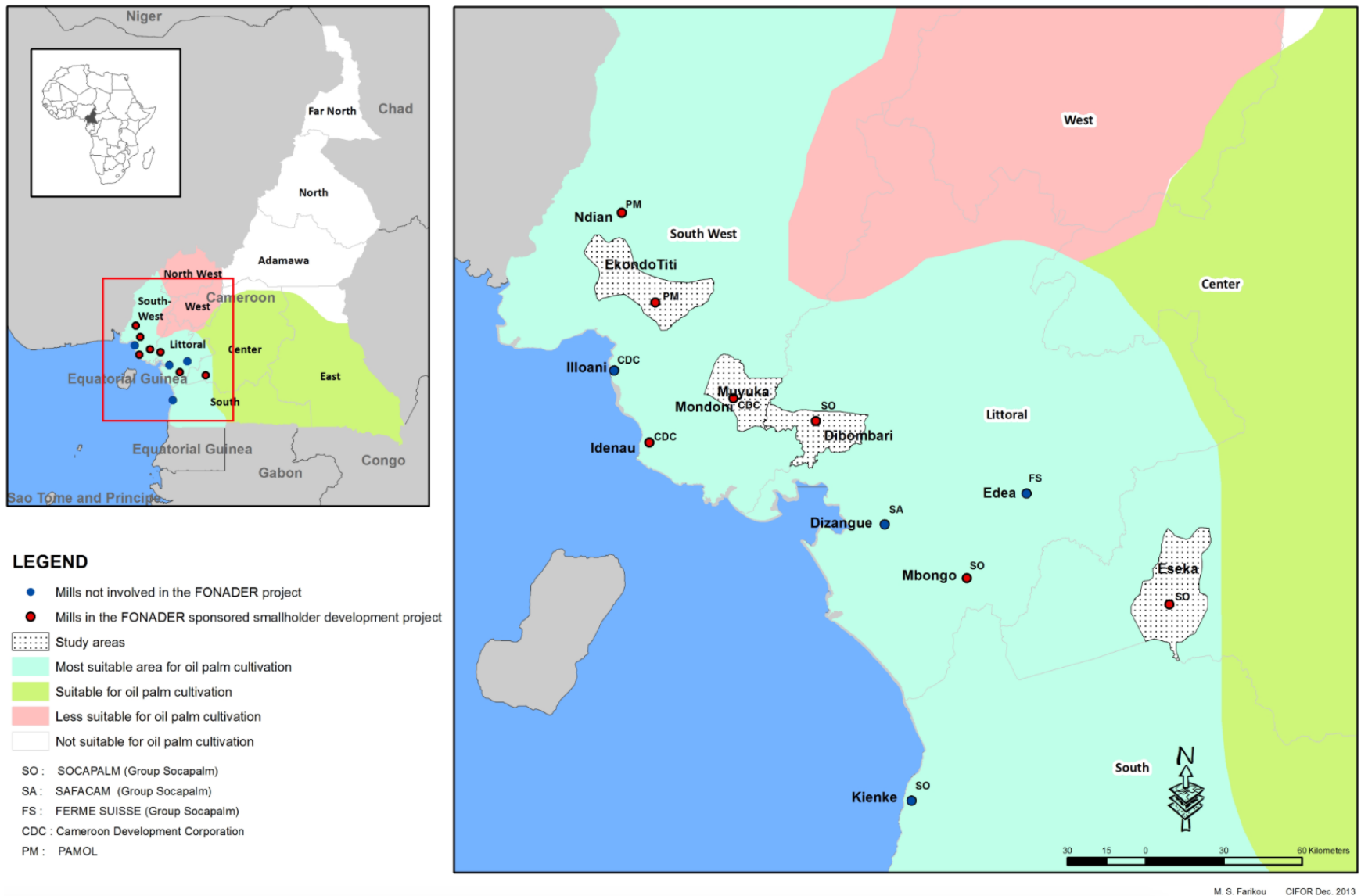

Figure 1. Production basins selected for the organization of the workshops - Bassins de production sélectionnés pour l'organisation des ateliers.

Table 1. Selection of participants for the workshops - Sélection des participants pour les ateliers.

\begin{tabular}{|c|c|c|c|c|c|c|}
\hline \multirow[t]{3}{*}{ Stakeholder } & \multicolumn{6}{|c|}{ Research site } \\
\hline & \multicolumn{2}{|c|}{ Eséka } & \multicolumn{2}{|c|}{ Ekondo Titi } & \multicolumn{2}{|c|}{ Muyuka } \\
\hline & Man & Woman & Man & Woman & Man & Woman \\
\hline Representatives of industries & 2 & & 3 & & 3 & \\
\hline Representatives of the Ministry of Agriculture & 2 & & & 1 & 1 & \\
\hline Independent growers & 2 & & 3 & & 2 & 1 \\
\hline Growers with a contract partnership with the industry & 5 & 1 & 4 & & 1 & \\
\hline Intermediaries, at the processing level & & 2 & & 1 & & 1 \\
\hline Representative of a microfinance institution & 1 & & & & & \\
\hline
\end{tabular}

\subsection{The system and its variables}

During a PPA workshop, participants build scenarios of the possible futures of a system. Discussions about the context help to identify and highlight the boundaries of this system. In this study, the general theme was the relationships between local actors of the palm oil sector. In each workshop, this theme was specified by the participants to define a system consisting of the actors in the palm oil sector, and including temporal and spatial boundaries. After the system was defined, variables influencing the evolution of the system were 
listed by the participants. In this exercise, variables could be understood as factors or objects influencing the system and likely to take several values. This step yielded a consensus on the set of variables to consider. Thereafter, discussions on the relevance and meaning of each of the selected variables allowed the final selection of variables. A precise and concise definition of each variable was posted on a wall and used for future discussions (as advised by Bourgeois \& Jésus, 2004).

\subsection{The relationships between variables}

The variables identified above might have between them relations of influence or dependence which could be direct or indirect. The relation of direct influence describes an induced causal link from one variable to another. The relationship of direct dependence reflects the subordination of one variable to another. The indirect influence is a case of transitivity where variable A influences variable B and variable B affects variable $C$. To conclude, variable $A$ influences indirectly variable $\mathrm{C}$. The total influence is the matrix product of the direct and indirect influences, and total dependence is the matrix product of direct and indirect dependencies (Bourgeois \& Jésus, 2004). The links between variables was analyzed using a gradient from 0 to 3 (0: no influence/no dependence, 3: strong influence/dependence).

During the workshop, the note keeper inserted the list of variables and the various values assessing the level of influence or dependence between the variables in a matrix prepared by Bourgeois \& Jésus (2004) in Microsoft Excel. Matrices of indirect and total influence/dependence were calculated automatically. The analysis of influence/dependence links helped to understand the role of each variable in the system.

Figure 2 shows the distribution of variables into four groups: driving variables, leverage variables, output variables and marginal variables. Driving variables are usually the first variables proposed by the participants and a consensus on their definition is easily obtained. When these variables change in value, they change the behavior of several variables and the overall system. Leverage variables have a strong influence and a strong dependence, hence are the center of the system. They change their state or value when driving variables change and the system is changing too. They may be used as indicators of change of the whole system; they generally correspond to stakes (Bourgeois \& Jésus, 2004). Product variables result from the actions of the key variables. Finally, the marginal variables are weakly influential and weakly dependent, their behavior in some cases can be dissociated from the system.

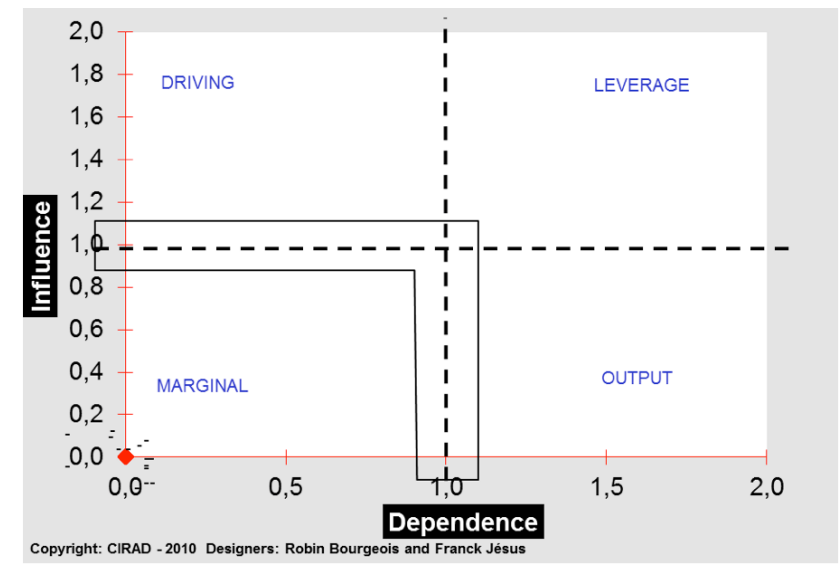

Figure 2. Overview of the importance of the variables' direct and indirect influence realized in the Excel spreadsheet designed by Bourgeois \& Jésus (2004) - Aperçu de l'importance de l'influence directe et indirecte des variables réalisé avec le tableur Excel, conçu par Bourgeois \& Jésus (2004).

\subsection{Building scenarios}

From the previous step, four to five variables were selected by the participants, based on their influence on the whole system. They belonged to drivers and levers variables and were named "key variables". For each of these variables, three states - or values - were defined. States must be plausible, meaning the variable could possibly take this state in the future. Scenarios were defined as a combination of possible states of the key variables. First, incompatibilities between variables' states were excluded, and then plausible combinations were proposed and discussed by the participants. Participants were then asked to select three of these combinations on which to work. The selection was made based on plausibility (likeliness to happen in the future) and by considering contrasting scenarios.

From this step, the participants divided into three working groups to develop the three scenarios. They used the results from the influence-dependence between variables exercise to discuss how a change in the state of the key variables would influence the other variables and the whole system. Finally they wrote down the story of the scenario.

\subsection{Anticipating actions}

In this step of the workshop, the participants identified desirable changes and the actions needed to modify the states of key variables in order to steer the changes of the whole system in the desired direction. The participants divided into three groups to describe actions and pathways to either avoid a non-desirable scenario or move toward a desirable one. The working 
groups presented their results in a plenary session, and a synthesis of actions to be implemented by the stakeholders was formulated. Recommendations were then written down and addressed to key stakeholders.

\section{RESULTS}

\subsection{Systems definition}

The topics to be discussed during each workshop were chosen by the stakeholders themselves. The topic chosen in Ekondo Titi was "Partnership between a union of smallholders and an agro-industry in Ndian division for the next 30 years"; in Eséka, "Partnerships between growers and a palm oil agro-industry in the Nyong and Kelle until 2050"; and in Muyuka, "Partnerships between an industry and smallholders to grow oil palm". The slight variations in the topics chosen were related to the actors present and the current level of organization of the farmers. Where farmers were already organized into cooperatives, "a union of smallholders" was considered. Where farmers were less organized, "out-growers" was preferred, and "organizations" appeared as a variable later in the workshop. The time horizon chosen in all of the sites reflected the average oil palm lifecycle of thirty years.

In Ekondo Titi, PAMOL prefers to deal with producer organizations rather than individual farmers. Community plantations and cooperatives are managed by families, groups of elites, and religious congregations, and often have official legal status (legalized). In Eséka, cooperatives exist, but their formation was prompted by the industrial mills rather than the growers themselves. Members have little trust in the management, which is weak, and smallholders do not view the cooperatives in a positive light.

\subsection{Variables affecting partnerships}

Variables affecting partnerships are listed in table 2 . In the three research sites, 28 variables were identified (see Appendix 1 for the complete list with definitions). In the two research sites where the PPA method was adopted, 15 variables were common to the two sites, out of a total of 19 variables identified in each site.
Common variables to all sites included technical and managerial capacity building, trust and transparency between partners, transportation arrangements, access to credit and good quality seedlings.

Figure 3 illustrates the influence of the variable, "Farmers' organization", on twelve variables in Eséka. The organization of growers has an impact on services such as technical capacity building, transportation of FFB to the mill, and access to inputs and seedlings. In Ekondo Titi, for example, producers' organizations have acquired tractors through collective credit. It also influences negotiations with the industry on prices, conflict management, and allows an active participation in the monitoring and evaluation of the partnership.

The main relevant drivers of the dynamics of partnerships between oil palm growers and agroindustry in Ekondo Titi (see Appendix 2) were: terms of the partnership contract between the industry and the out-growers, access to managerial capacity building for smallholders, cooperatives, access to technical capacity building for out-growers, road network quality, and access to holding shares in the mill for the union of smallholders. Transparency, trust, continuous monitoring-evaluation of the partnership and access to credit emerged as levers of the dynamics of the partnership. In Eséka (see Appendix 3), legalization of the contract (meaning official and formal recognition by a public authority), terms of the contract, technical capacity building, and quality of the road network were also qualified as main drivers of the dynamics of the system. In addition, two other variables were qualified as drivers: adaptation of the contract to national public

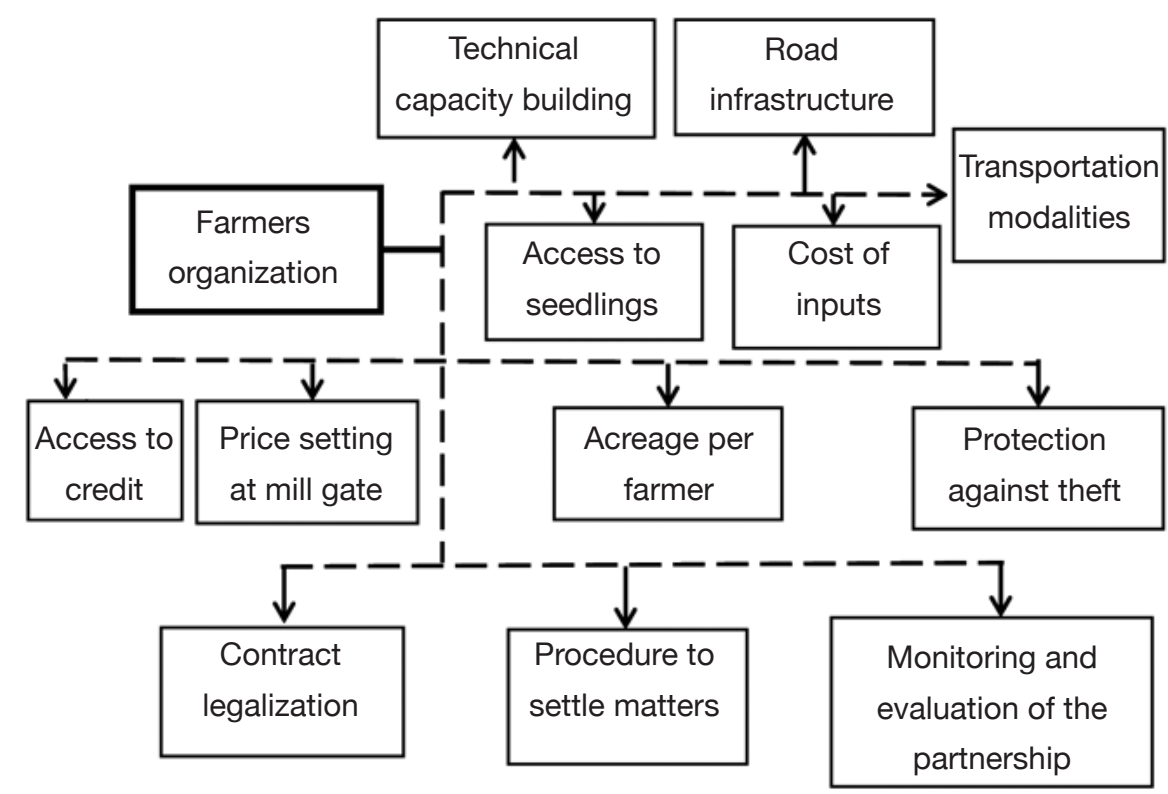

Figure 3. Influence of "farmers' organization" on 12 variables regarding partnerships - Influence sur 12 variables de la variable " organisation de producteurs » concernant les partenariats. 
Table 2. Occurrence of variables in the research sites - Occurrence des variables pour les différents sites de recherche.

\begin{tabular}{|c|c|c|c|c|}
\hline $\mathbf{N}$ & Variable & Eséka & Ekondo Titi & Muyuka \\
\hline 1 & Adaptation of the contract to public policy & $\times$ & & \\
\hline 2 & Public policy on access to land & & $\times$ & $\times$ \\
\hline 3 & Access to technical capacity building & $\times$ & $\times$ & $\times$ \\
\hline 4 & Payment of growers & & & $\times$ \\
\hline 5 & Access to managerial capacity building & & $\times$ & $\times$ \\
\hline 6 & Presence and quality of road infrastructure & $\times$ & $\times$ & $\times$ \\
\hline 7,8 & Trust and transparency between growers & $\times$ & $\times$ & $\times$ \\
\hline 9 & Legalization of the partnership contract with specified terms & $\times$ & $\times$ & $\times$ \\
\hline 10 & Negotiation of the terms of the contract & & & $\times$ \\
\hline 11 & Procedures for monitoring and evaluation of the partnership & $\times$ & $\times$ & \\
\hline 12 & Access to credit & $\times$ & $\times$ & $\times$ \\
\hline 13 & Access to good quality seedlings & $\times$ & $\times$ & \\
\hline 14 & Terms of pricing schemes & $\times$ & $\times$ & $\times$ \\
\hline 15 & Theft control & $\times$ & $\times$ & $\times$ \\
\hline 16 & Industrial mill capacity & $\times$ & $\times$ & \\
\hline 17 & Transportation modalities of FFB and inputs & $\times$ & $\times$ & $\times$ \\
\hline 18 & $\begin{array}{l}\text { Shareholding involvement of the union of smallholders with the agro-industrial } \\
\text { company }\end{array}$ & & $x$ & \\
\hline 19 & Access to agricultural inputs & & $\times$ & $\times$ \\
\hline 20 & Mill location & & $\times$ & \\
\hline 21 & Labour availability & & $\times$ & $\times$ \\
\hline 22 & Producer organizations & $\times$ & & $\times$ \\
\hline 23 & Acreage per planter & $\times$ & & \\
\hline 24 & Procedures to settle conflicts & $\times$ & & $\times$ \\
\hline 25 & Yields of fruits & $x$ & & \\
\hline 26 & Cost of inputs & $x$ & & \\
\hline 27 & Tax regime for fruit growers & $\times$ & & \\
\hline 28 & Existence of a department in charge of relations with growers in the company & $\times$ & & $\times$ \\
\hline
\end{tabular}

policy, and trust and transparency among partners. The organization of growers, modalities of monitoring and evaluation of the partnership, and the surface area per grower emerged as levers.

The two PPA workshops ended up with similar sets of drivers and levers. In the third workshop, in Muyuka, terms of the contract, trust and transparency, organization of smallholders, modalities of monitoring and evaluation, and road maintenance were also selected as the main factors of success of a partnership. In addition, the existence of a division within the agroindustry dedicated to relations with out-growers was considered as essential to the long-term management of the partnership.

Figure 4, based on discussions in Ekondo Titi, summarizes the relations of influence and dependence among the variables. Trust and transparency appeared clearly in a position of leverage, with influence on and dependence from most of the other variables. Terms of the contract, shareholding in the company, access to managerial capacity building, and monitoring and evaluation of the partnership were positioned above the other variables, as drivers of major influence. Other variables were related to each other, but had low global influence, and thus were outputs, or what we refer to as "marginal". This scheme reflects the quantitative results obtained from the exercise of the influence-dependence analysis of variables, also shown in Appendix 2.

Understanding the dynamics of how a partnership between an industry and oil palm growers functions naturally leads to a discussion of the conditions of a sustainable and fair partnership. 


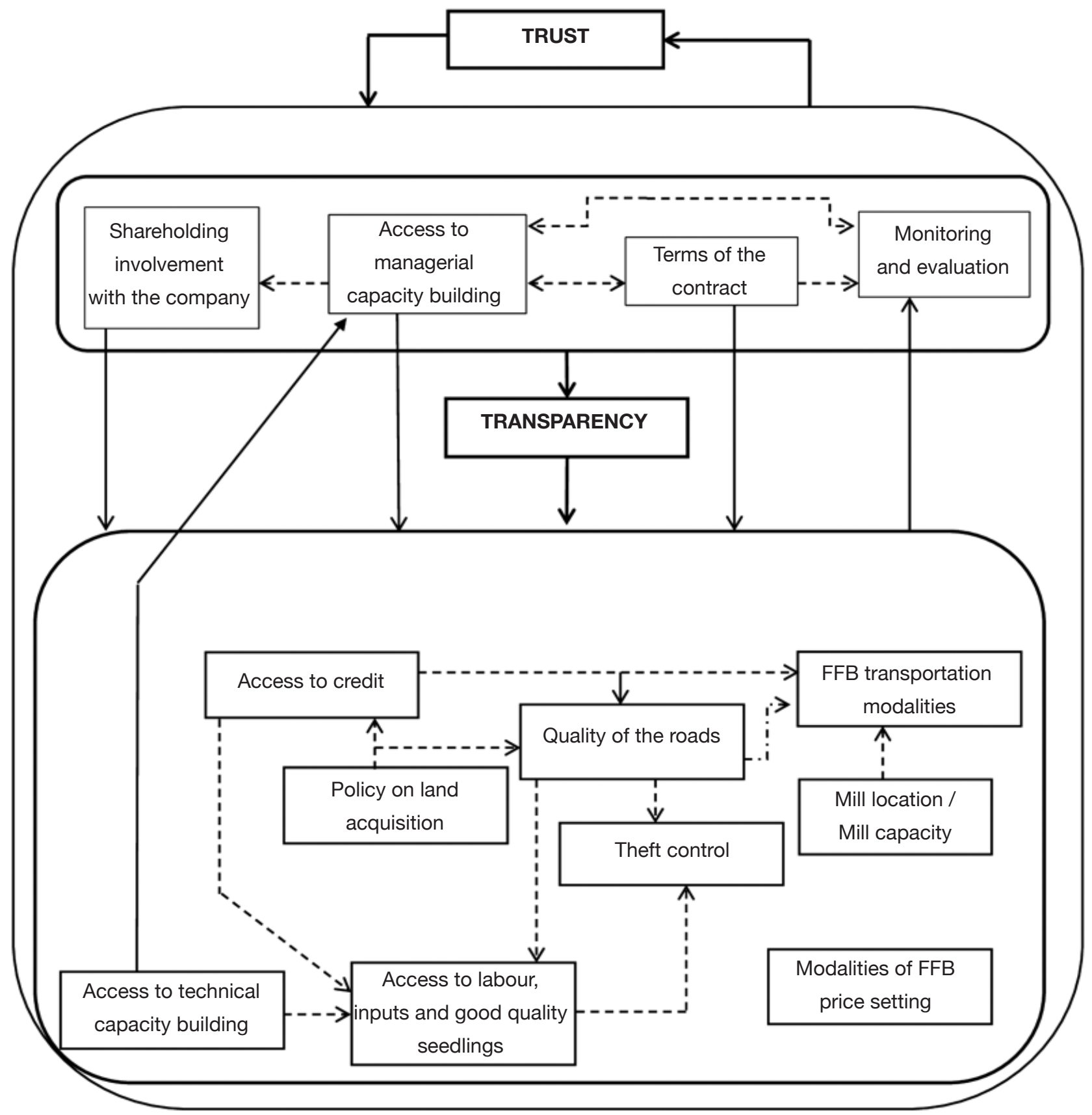

Figure 4. Relationship among the variables for Ekondo Titi - Relations entre variables pour Ekondo Titi.

\subsection{Working on possible futures, conditions for a sustainable and fair partnership}

Organizing the partners for better management and communication. Workshop participants identified the first prerequisite for the establishment of a sustainable partnership as the creation of a climate of trust between partners. They consequently felt that it was fundamental for both partners to negotiate the terms of the contract before engaging themselves in the partnership. They agreed that an enabling environment depends on better communication, transparency, and a formal and legalized contract with clear details on the commitments of each party, their responsibilities, the way operations are run and the application of penalties. Table 3 highlights most elements that should appear in a contract according to the participants.

UNEXPALM agreed and specified a need for two types of contracts: a production agreement binding the oil palm growers to a cooperative (including the minimum tonnage of FFB to be provided by the grower per season, the services provided by the cooperative, 
Table 3. Elements to be discussed and included in a contract of partnership - Éléments susceptibles d'être discutés et à inclure dans un contrat de partenariat.

\begin{tabular}{llll}
\hline Core item & Eséka & Ekondo Titi & Muyuka \\
\hline Definition and contract objectives & $\times$ & $\times$ & $\times$ \\
\hline Modalities of FFB transportation & $\times$ & $\times$ & $\times$ \\
\hline Process of price setting modalities & $\times$ & $\times$ & $\times$ \\
\hline Contract failure conditions & $\times$ & $\times$ & $\times$ \\
$\begin{array}{l}\text { Penalties in case of contract } \\
\text { infringement }\end{array}$ & $\times$ & $\times$ & $\times$ \\
$\begin{array}{l}\text { Documentation of conflict } \\
\text { resolution process }\end{array}$ & $\times$ & $\times$ & $\times$ \\
\hline Legal recognition of the contract & $\times$ & $\times$ & $\times$ \\
\hline Terms of technical assistance & $\times$ & & $\times$ \\
$\begin{array}{l}\text { Interest rates for debt repayment } \\
\text { could be: from } 0 \text { to 7 years: } 5 \%,\end{array}$ & & $\times$ & $\times$ \\
8 to 15 years: $10 \%$ & & $\times$ \\
\hline Agreement on payment modalities & & $\times$ & $\times$ \\
\hline $\begin{array}{l}\text { Identity of the contractors } \\
\text { Lifespan of the contract }\end{array}$ & & $\times$ & $\times$ \\
\hline \begin{tabular}{l} 
Farm characteristics, location \\
\hline
\end{tabular} & & $\times$ \\
\hline
\end{tabular}

of the cooperatives could be supervised and supported through systems of mutual guarantee and collective enforcement. The bargaining power of oil palm growers would be reinforced.

Defining clear responsibilities of the partners. The participants considered that the department in charge of relationships with out-growers within the industrial partner should be responsible for organizing the collection of FFB from out-growers' plantations, and paying the producers on time. In addition, it should be responsible for providing inputs and good quality planting material at industry-purchased price to farmers, eventually as in-kind credit. It could facilitate access to credit from microfinance institutions or banks by providing guarantees to their partners, and organize capacity building programs on technical and management issues, and provide individual technical assistance to out-growers. It could also manage FFB price setting, to be agreed beforehand on a negotiated basis before the signature of the contract and clearly stated. Producers could the costs, etc.), and a sale agreement between the cooperatives and the processing plant. The contract with the mill should specify the quantities of FFB to be sold, the rules of price setting and quality standards. Such an approach would improve the traceability of Crude Palm Oil (CPO).

According to the participants, good monitoring of the partnership relies on clear communication channels. One key to the success of the partnership would be the existence of a division or department dedicated to smallholders in the industrial partner. Another important element would be the organization of oil palm growers into farmers' organizations or cooperatives with elected delegates who could legitimately represent them in meetings and negotiations with the industrial partner.

Currently, most farmers' cooperatives lack management skills. In Ekondo Titi, farmers' organizations wishing to deal with the industry must be duly registered and be at least five years old. These conditions are set up to ensure the reliability of the organization. The demand for management capacity building was clearly expressed by the participants in the three workshops, and given the same importance as technical capacity building.

UNEXPALM wished to become an umbrella organization, acting as a national platform of cooperatives of smallholders and big plantation owners. Services to farmers and inputs would be handled through this organization. The management be paid bonuses based on quality criteria defined in the contract, which could be in the form of CPO given back to smallholders for family consumption and gifts.

The out-growers might organize themselves into formal organizations such as cooperatives, and elect their representatives. Each grower should be involved in a cooperative, and each cooperative member should be aware of the terms of the contract before signing it. Their first responsibility would be to supply FFB to the mill, and collectively as cooperatives, to achieve the targeted production goals. The cooperatives would be responsible for keeping records for each member about production and sale of FFB to the mill, input acquisition, financial, managerial, and technical capacity building required and obtained. The department in charge of the relationships with out-growers in the industrial partner would keep similar records. A regular comparison of the cooperatives' and industrial partner's records would ensure transparency. Cooperatives should also promote the registration of their members in the capacity building programs offered by their partner. Members of the cooperative should commit to participating in the capacity building programs and following the technical recommendations provided by the cooperative.

Farmers' organizations and agribusiness may define a formula for their respective contributions to a fund for road maintenance. The communities may be involved in the classification and prioritization of roads for agricultural use, the monitoring and evaluation of 
road networks (selection of qualified contractors), and be involved in preliminary studies for writing projects for the development of new roads to be submitted to government services and donors.

Ensuring trust and transparency between partners. Participants agreed on the need for the continuous monitoring and evaluation of the partnership. A platform including the agribusiness, a representative of the Ministry of Agriculture, and producer organizations was proposed to assure the overall monitoring and evaluation of the partnership and to take appropriate action to resolve potential problems and difficulties encountered. The procedure for dispute resolution should be clear and easily accessible to all.

The participants emphasized that the terms of a contract should not be modified without previous negotiation and written consent from all parties.

The participants proposed that communication should be organized with channels of dissemination and regular meetings. Communication should consist in planning and advertising activities involving both parties posted in reports to be published according to a fixed schedule. Industry and growers' representatives should meet according to this calendar. Record books should be checked during these meetings. Each participant should have the right to get a copy of the report of the meeting, accessible and available to everyone. In addition, meetings between the executive board of the industrial company and representatives of cooperatives were requested on a regular basis at least twice a year at the general assembly of the cooperatives to ensure direct communication.

UNEXPALM emphasized the relevance of transparency in terms of actual production costs and advocated that this be included in price setting. Participants in Eséka insisted on the presence of a representative of the growers in weighing operations when delivering FFB to the mill.

Some final details were suggested by the participants, such as members of cooperatives should be represented on the executive board of the mill when the cooperatives held shares in the mill. In the case of a simple partnership without participation in the financial capital, a liaison officer from the cooperatives should attend the meetings of the executive board. Similarly, the industry should have a liaison officer within the union of farmers who attends the general meetings.

\section{DISCUSSION}

\subsection{Relevance of the results}

The use of the PPA method resulted in the emergence of a similar set of variables across two research sites, which also were very similar to the results from a third site. The three research sites represent the three principal palm oil production basins in Cameroon as well as the three current palm oil producing companies, and the workshops gathered representatives from all of the stakeholders of the sector in the country. The results consequently can be considered to be relevant for the country as a whole. The discussion of the workshops' results with national scale actors confirmed this relevance. Furthermore, the outputs of the workshops are very timely and accurate in the present context of agricultural modernization in Cameroon. The contractual terms defined in a participatory manner during this research could serve as a basis for further development of a public policy for more equitable partnerships.

Smallholders expressed the opinion that becoming shareholders in the company would pave the way for the development of new win-win arrangements. Recent developments in Columbia favor the development of joint ventures named "alliances". Within an alliance, the government helps the company to provide technical assistance and access to credit and inputs for farmers grouped in organizations, which hold shares in the company. Alliances organize production partnerships between companies and smallholders grouped in cooperatives with about 1 to 4 ha of oil palm each (Pacheco, 2012). In Cameroon, new legislation should be developed to allow such a promising system. In addition to this, new legislation could support the creation of smallholder departments in the agroindustrial companies to be a direct interlocutor for farmers, facilitating communication and favoring transparency.

Beyond Cameroon, our results can be used as trails to develop generic recommendations for fair and sustainable partnerships between smallholders and industries. In Indonesia, where NES projects can lead to violent and unresolved conflicts (Feintrenie et al., 2010), the PPA workshops could help production partners to collectively find solutions and move forward.

\subsection{Reflecting on the PPA method}

Strengths. The interaction process inherent in the PPA method greatly facilitated the understanding of drivers that influence institutional arrangements between stakeholders. The process also enabled stakeholders to set new rules in a participatory way, thus turning even restrictive rules into win-win arrangements. Participants liked the participatory and interactive process; they appreciated the possibility to express themselves openly and to have their views taken into consideration. They considered the theme addressed as being relevant to their needs. To overcome obstacles 
created by shyness and to ensure that all participants could freely express their opinions, the facilitators often invited participants to write anonymously on a piece of paper. This was especially the case for the list of variables influencing the system, the possible states of key variables, and the definition of scenarios. The division into small groups of 3 to 4 participants during the last stages of the workshop also facilitated the participation of all.

The proper implementation of the method requires that all stakeholders involved in the system are represented. While the workshops involved a maximum of 12 participants, the typology defined in previous studies was essential to target representative stakeholders. Preliminary studies are needed to select knowledgeable participants. In our case, the assessment of the oil palm value chain facilitated the selection of stakeholders representing the sector. The ARDI - Actors, Resources, Dynamics, Interactions method (Etienne et al., 2011) could be recommended as a preliminary step to PPA. It is designed as a step-bystep exercise at a territory level where actors, resources and the surrounding dynamics are identified.

Inviting actors representing conflicting interests to sit around a table usually results in discourteous exchanges. Starting with the definition of the system and the listing of variables, which influence the system, helps to cool down the debate and renders interventions more objective and constructive. This step helps to gain some perspective on current and unpleasant reality, and focus on positive possible developments in the medium and long term. The use of a participatory process throughout the workshops ensured the acceptance of the ideas of others and led to the construction of a common vision. The lack of a strict method to transcend each participant's stakeholder position probably explains the lower participation in the semi-directed approach followed in the Muyuka workshop.

The risk of facilitators influencing the discussion in participatory research is quite high due to the openperspective of the exercise. The PPA method provides some solutions to improve rigor during discussions. For instance, it became obvious during the process that the same words may have different meanings for different actors. To avoid such problems, after having identified the variables, the participants discussed and agreed on the precise meaning of each variable. The final list of the variables with their consensual definitions was set and displayed on a paper board. The list acted as a compass, which helped to focus the discussion when participants wandered off-topic.

Limitations. Given the complexity of some exercises in the workshops, the level of education and familiarity with abstract intellectual exercises of certain participants were critical. The PPA method provided an opportunity for local stakeholders to express themselves. However, some important variables influencing partnerships may not come up during exchanges. Due to their position as local stakeholders, they were generally unaware of higher level variables. This was the case in our study sites, for example for fluctuating world prices of CPO and national land issues. This also applies to workshops at a national level, assuming that experts' perspectives are often different or even opposite from those of local actors.

\subsection{Participatory design for agricultural systems and value chain development}

Relevance of participatory methods to solve conflicts. In our study sites, conflicts were a legacy of a very long history, begun during colonial times, of oneway decisions, lack of communication, and mistrust. All of the stakeholders considered themselves as victims of non-respect of their engagements by third parties, and felt unfairly accused of what their predecessors had done. Preliminary discussions, at the opening of each workshop, were tense. The impersonal activity of defining variables and writing on cards helped to calm the atmosphere. The next PPA step of discussing influence-dependence relations led to sharp discussions on what often were non-important (marginal) variables, but these ended amicably once the facilitators put the discussion in perspective ("You are fighting to decide if the influence of variable A on variable B is a 2 or 3 !'). In the workshop conducted in Muyuka, where a semi-guided participatory approach was followed, this opportunity to discuss and concentrate on precise factors to forget about individual suspicions was absent. As a result, the participants were less motivated to share their opinions and ideas.

The selection of participants was also critical, as the interaction of multiple stakeholders helps to create a consistent system thanks to the integration of various viewpoints and to solve conflicts.

Relevance of prospective approaches to design agricultural systems. Prospective approaches focus on understanding present situations to engage in foresight exercises and are "solution oriented". They can help design innovations, as reported by Laumonier et al. (2008) in Indonesia. In the process, a better understanding of the traditional system by the stakeholders facilitates the identification of production shortages and initiates relevant research in agricultural improvements.

Delgado et al. (2016) reported the efficiency of adapting prospective structural analysis for institutional capacity building at the community level in order to promote a more sustainable management of natural resources. 
Relevance of participatory prospective analysis to design new policies. Participatory processes are used increasingly in strategic policy planning. They foster the integration of various viewpoints regarding local to national development concerns to design agricultural and conservation policies. In a PPA conducted in the Congo Basin, panels regrouping experts from different backgrounds proposed consensual policy recommendations on the management of activities within forests and public policy orientations that were able to favor the sustainable exploitation of the forests (Marien \& Bassaler, 2013).

Along the same lines, Etienne et al. (2011) presented case studies demonstrating how participatory approaches can usefully advise policy makers by gathering local perspectives through qualitative and quantitative computer simulation models.

\section{CONCLUSIONS}

The recommendations adopted by the stakeholders during this study should be taken into consideration by policy makers for the drafting of rules and regulations regarding contract farming arrangements between agro-industries and smallholders in the palm oil sector. Such partnerships, approved by the agro-industries and smallholder cooperatives, would considerably increase oil production at the level of the production basin and be replicable in other parts of the country, with a strong multiplier effect. Presently, emerging commodity-based initiatives are encouraging civil society, communities as well as other stakeholders, to play a more important role in the implementation of agricultural policies. In Cameroon, in a context of growing pressure on land, public policies could be drafted to incite agro-industries to develop fair and sustainable partnerships with smallholder cooperatives. Corporate social responsibility might be one way to fund capacity building of smallholders and cooperative managers.

\section{Acknowledgements}

Authors are grateful to the SPOP project (http://spop.cirad. fr) and ANR (French National Research Agency) who supported this research with the program Agrobiosphere 2011 (ANR-11-AGRO-0007). This research was carried out as part of the CGIAR Research Program on Forests, Trees and Agroforestry (CRP-FTA). This collaborative program aims to enhance the management and use of forests, agroforestry and tree genetic resources across the landscape from forests to farms. The Center for International Forestry Research (CIFOR) leads CRP-FTA, in partnership with Bioversity International, Centro Agronómico Tropical de Investigación y Enseñanza (CATIE), Agricultural Research for Development (CIRAD), the International Center for Tropical Agriculture (CIAT), and the World Agroforestry Centre (ICRAF). The authors are grateful to all the contributors to the CGIAR Fund (https://www.cgiarfund. org/FundDonors).

\section{Bibliography}

Abdullah A.H., $\quad$ Aziz R.A. \& Mohamad S., 1987. Development and socio-cultural changes in rural Malaysia. Akademika, 30, 29-48.

Bakoumé C. et al., 2002. Études complémentaires sur la relance des filières hévéa et palmier à huile. Rapport de consultation pour l'organisation. Yaoundé : IRAD/ CIRAD/IITA/FAO.

Bourgeois R. \& Jésus F., 2004. Participatory Prospective Analysis, exploring and anticipating challenges with stakeholders. Monographs $\mathrm{N}^{\circ} 46$. Bogor, Indonesia: Centre for Alleviation of Poverty through Secondary Crops Development in Asia and the Pacific.

Cramb R.A. \& Ferraro D., 2012. Custom and capital: a financial appraisal of alternative arrangements for large-scale oil palm development on customary land in Sarawak, Malaysia. Malaysian J. Econ. Stud., 49(1), 4969.

Delgado-Serrano M. et al., 2016. Adapting prospective structural analysis to strengthen sustainable management and capacity building in community-based natural resource management contexts. Ecol. Soc., 21(2), 36.

Elong J.G., 2003. Les plantations villageoises de palmier à huile de la Socapalm dans le bas-Moungo (Cameroun) : un projet mal intégré aux préoccupations des paysans. Cah. Outre-Mer, 224, 401-418.

Etienne M., Du Toit D.R. \& Pollard S., 2011. ARDI: a co-construction method for participatory modeling in natural resources management. Ecol.Soc., 16(1), 44.

Feintrenie L., 2014. Agro-industrial plantations in Central Africa, risks and opportunities. Biodivers. Conserv., 23(6), 1577-1589.

Feintrenie L., Chong W.K. \& Levang P., 2010. Why do farmers prefer oil palm? Lessons learnt from Bungo district, Indonesia. Small-scale For., 9(3), 379-396.

Foko E., 1994. Les paysans de l'Ouest Cameroun face au crédit agricole institutionnel. Écon. Rurale, 219, 12-15.

Iyabano A.H., 2013. Analyse socio-économique de la filière artisanale d'huile de palme dans la région de la Sanaga-Maritime (Cameroun). Thèse de Master: Institut Agronomique et Méditerranéen de Montpellier Université Paul Valéry Montpellier III, Montpellier (France).

Konings P., 1986. L'État, l'agro-industrie et la paysannerie au Cameroun. Politique Afr., 22, 120-137.

Laumonier Y.,Bourgeois R.\& Pfund J.-L.,2008.Accounting for the ecological dimension in participatory research and development: lessons learned from Indonesia and Madagascar. Ecol.Soc., 13(1), 15. 
Levang P., 1997. La terre d'en face : la transmigration en Indonésie. Paris : Orstom.

Maley J., 1999. L'expansion du palmier à huile (Elaeis guineensis) en Afrique centrale au cours des trois derniers millénaires : nouvelles données et interprétations. In : Bahuchet S., Bley D., Pagezy H. \& Vernazza-Licht N. L'homme et la forêt tropicale. Marseille, France : Société d'écologie humaine, 237-254.

Marien J.N. \& Bassaler N., 2013. Éléments de prospective à l'horizon 2040 pour les écosystèmes forestiers d'Afrique centrale. Rapport technique de synthèse final. Yaoundé : Commission des Forêts d'Afrique Centrale.

Nchanji Y.K., Tataw O., Nkongho R. \& Levang P., 2013. Artisanal milling of palm oil in Cameroon. Working Paper 128. Bogor, Indonesia: Center for International Forestry Research.

Ndjogui T.E. et al., 2014. Historique du secteur palmier à huile au Cameroun. Document occasionnel 109. Bogor, Indonésie : Centre International de Recherche en Foresterie.

Ngom E., Simb M. \& Benga F., 2016. Etat d'avancement des activités au Programme de Développement des Palmeraies Villageoises (PDPV). Rapport provisoire. Yaoundé : Ministère de l'Agriculture et du Développement Rural.

Nkongho R., Feintrenie L. \& Levang P., 2014a. The strengths and weaknesses of the smallholder oil palm sector in Cameroon. Ol. Corps Gras, Lipides, 21(2), D208.

Nkongho R.N., Nchanji Y., Tataw O. \& Levang P., 2014b. Less oil but more money! Artisanal palm oil milling in Cameroon. Afr. J.Agric. Res., 9(20), 1586-1596.

Olagunju F.I., 2008. Economics of palm oil processing in Southwest Nigeria. Int. J. Agric. Econ. Rural Dev., 1(2), 69-77.

Pacheco P., 2012. Soybean and oil palm expansion in South America, a review of main trends and implications. Working Paper $\mathrm{n}^{\circ} 90$. Bogor, Indonesia: Center for International Forestry Research.

Rival A. \& Levang P., 2013. La palme des controverses, palmier à huile et enjeux de développement. Versailles, France : Quæ éditions.

(24 ref.) 
Appendix 1. List of variables and their definitions - Liste des variables et leur signification.

Variable
Adaptation of the contract to public policy
Public policy on access to land
Access to technical capacity building
Access to managerial capacity building
Presence and quality of road infrastructure

Trust and transparency between growers

Definition

The variable refers broadly to the State's involvement to give priority to disadvantaged groups

The priority for land access for marginalized groups (women, youth and poor)

Concerns the agronomic and technical advice provided to farmers for production

Refers to payment deadlines of farmers by the company. Delay between the deliveries of bunches to the Company and payment. Presently, this period ranges from 20 days to two months

Represents all the training on financial, management practices, business management, record keeping, human resources management and the strengthening of the cooperative's dynamism

The first meaning is understood as the density, quality, and length in kilometers of road access to plantations and mills. The other meaning was designated as the connection of rural roads from the plantations to the main roads and building bridges

This variable was defined first as the morality of cooperative leaders, equity in redistribution of benefits, compliance with contractual clauses. Secondly, the variable measures the level of trust between the two partners and fosters the sharing of data and information on the activities of smallholder plantations and industrial estates

Legalization of the partnership contract with specified terms

Refers to the legal recognition of the partnership contract

Negotiation of the terms of the contract

The variable refers to negotiations during the drafting and validation of the contract terms by both parties. It refers to all details, agreements and obligations of each party

Procedures for monitoring and evaluation of the partnership.

Can be defined as the process of monitoring of compliance with contract terms by both parties. It can be done through ongoing assessments, verification of compliance with contractual clauses, control and external evaluation

Access to credit

The expected use of the credit. In the short term: for maintenance, purchase of equipment, acquisition of inputs; in the long term for investments. It also refers to the ability of planters to access credit from a microfinance institution with the help of agro-industries. Finally, the variable refers to inkind credit to be distributed by the company to farmers in the form of inputs

\begin{tabular}{ll} 
Access to good quality seedlings & $\begin{array}{l}\text { Refers to high-yielding seeds and seedlings, of certified quality and disease } \\
\text { resistant }\end{array}$ \\
\hline Terms of pricing schemes & $\begin{array}{l}\text { Refers to the negotiation process between growers and agro-industry and the } \\
\text { items to be considered to set the price for FFB }\end{array}$ \\
\hline Theft control & $\begin{array}{l}\text { Refers to the design of a participatory mechanism to fight against theft both } \\
\text { in smallholder and industrial plantations }\end{array}$ \\
\hline Industrial mill capacity & $\begin{array}{l}\text { Is defined as a mill's maximum processing capacity of FFB per hour } \\
\text { Transportation modalities of FFB and } \\
\text { inputs }\end{array}$ \\
$\begin{array}{l}\text { Refers to the transportation of FFB to the plant and inputs to the } \\
\text { smallholders' plantations. Specific parameters for transportation } \\
\text { modalities should include the cost per kilometer, per ton, frequency and } \\
\text { the characteristics of vehicles, among other parameters. An alternative } \\
\text { to consider the transportation of FFB to the mill by a planter could be } \\
\text { considered, while taking the cost supported by the farmer into consideration } \\
\text { for reimbursement }\end{array}$ \\
\hline
\end{tabular}


Appendix 1 (continued). List of variables and their definitions - Liste des variables et leur signification.

\begin{tabular}{|c|c|}
\hline Variable & Definition \\
\hline $\begin{array}{l}\text { Shareholding involvement of the union } \\
\text { of smallholders with the agro-industrial } \\
\text { company }\end{array}$ & $\begin{array}{l}\text { Means opening the access to shares of the agro-industrial company to the } \\
\text { union of smallholders or cooperative involved in the partnership }\end{array}$ \\
\hline Access to agricultural inputs & $\begin{array}{l}\text { Refers to the access to fertilizers, pesticides, herbicides and various } \\
\text { equipment. It is also related to the purchasing power of farmers }\end{array}$ \\
\hline Mill location & $\begin{array}{l}\text { Refers to the location of village plantations related to the processing plant } \\
\text { (mill) }\end{array}$ \\
\hline Labor availability & $\begin{array}{l}\text { Refers to labor market characteristics: labor availability in industrial estates } \\
\text { is linked to the level of smallholder development, existence of other self- } \\
\text { employment opportunities (such as phone box, motorcycle taxi, etc.) }\end{array}$ \\
\hline Producer organizations & $\begin{array}{l}\text { It represents the shared vision, the mutual understanding between growers, } \\
\text { the pooling of resources, the bargaining power of smallholders grouped in } \\
\text { a cooperative. Another aspect is linked to the development of small-scale } \\
\text { processing of palm oil as an alternative to industrial mills }\end{array}$ \\
\hline Acreage per grower & The surface area of a plantation owned by a planter \\
\hline Procedures to settle conflicts & Refers to the framework for dispute resolution if necessary \\
\hline Yields of fruits & Relates to FFB produced per hectare of oil palm plantation per year \\
\hline Cost of inputs & $\begin{array}{l}\text { Refers to the purchase price of fertilizers in addition to the charge of } \\
\text { transport and handling }\end{array}$ \\
\hline Tax regime for fruit growers & $\begin{array}{l}\text { Refers to the level of taxation schemes of smallholders FFB while } \\
\text { delivering to the agro-industry }\end{array}$ \\
\hline $\begin{array}{l}\text { Existence of a department in charge of } \\
\text { relations with growers in the company }\end{array}$ & $\begin{array}{l}\text { Refers to the unit dedicated to the daily management of the partnership with } \\
\text { smallholders in an agro-industry }\end{array}$ \\
\hline
\end{tabular}




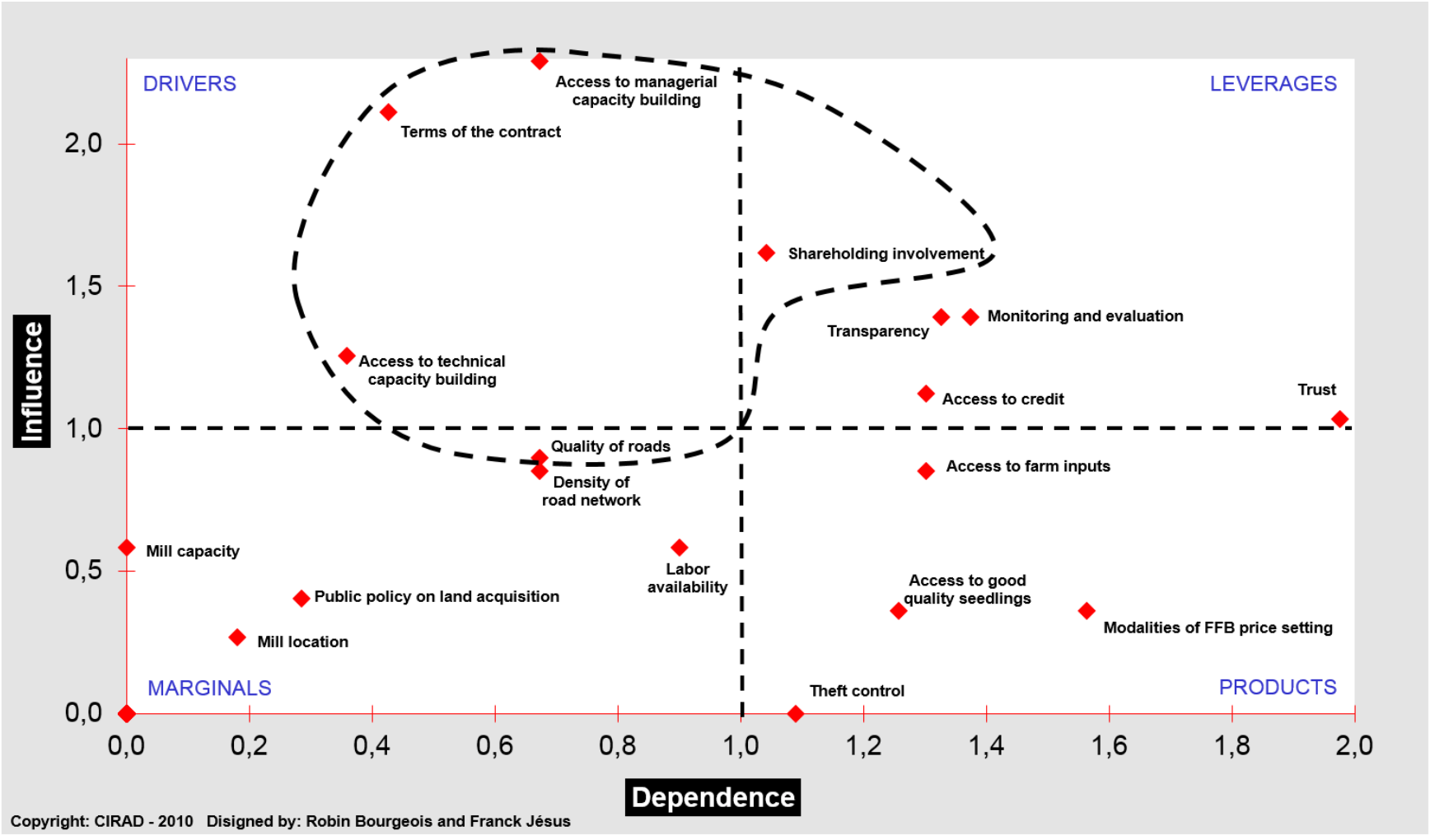

Appendix 2. Overview of the importance of the variables (direct and indirect influences) in Ekondo Titi - Aperçu de l'importance des variables (directes et indirectes) pour le site d'Ekondo Titi.

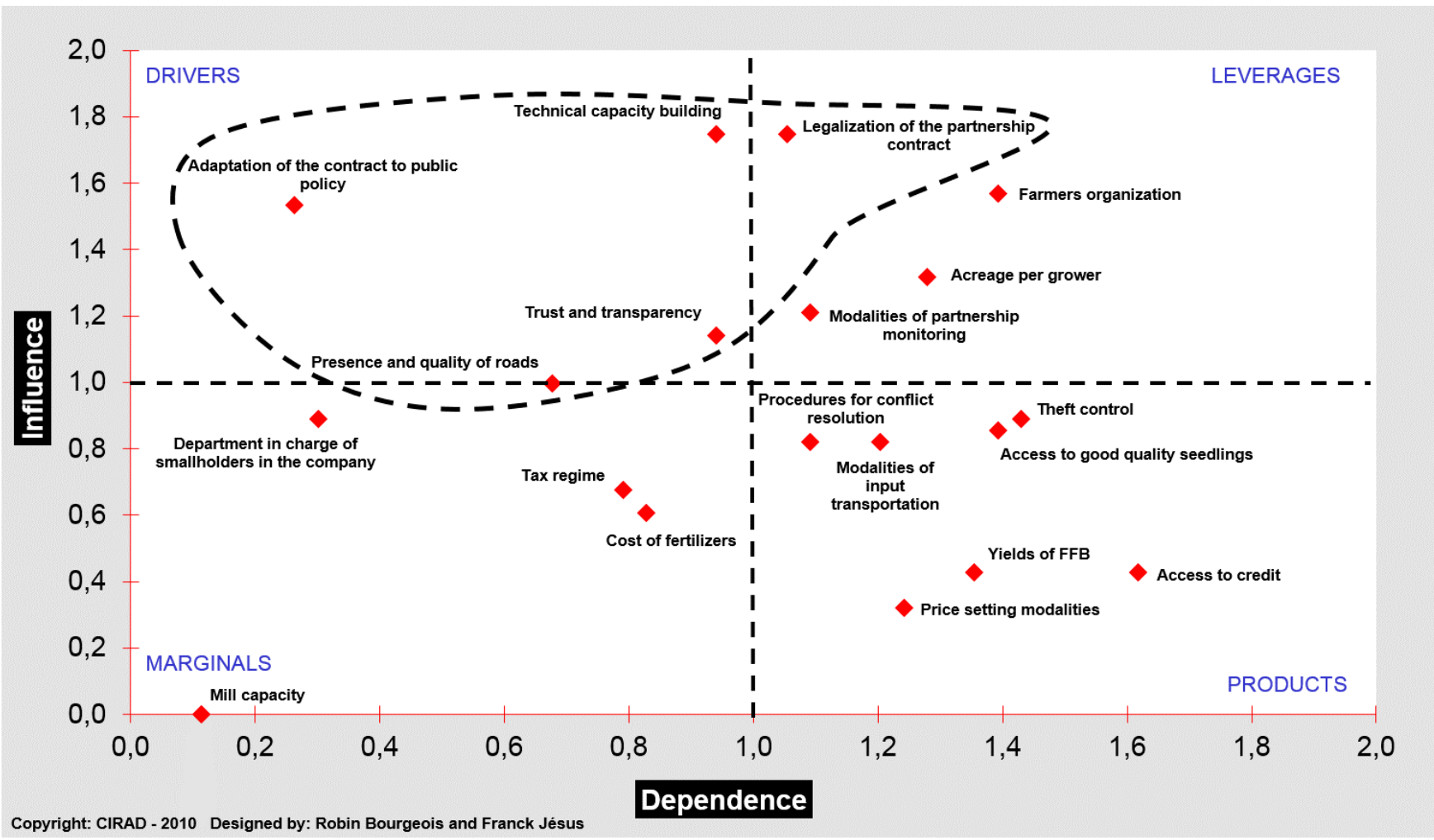

Appendix 3. Overview of the importance of the different variables (direct and indirect influences) in Eséka - Aperçu de l'importance des variables (directes et indirectes) pour le site d'Eséka. 